\title{
Effect of Fertigation Levels on Soil Available Nutrients Status and Nutrients Uptake by Cabbage (Brassica Oleracea L. Var. Capitata)
}

\author{
Mohammadullah Nikzad", J. S. Aravinda Kumar, B. N. Dhananjaya, \\ M. Anjanappa and H. Amarananjundeswara \\ College of Horticulture, UHS Campus, GKVK, Bengaluru-65, India \\ *Corresponding author
}

\section{Keywords}

Fertigation,

Nutrients, Nutrients

Uptake, Water

Soluble Fertilizers

Article Info

Accepted:

08 January 2020

Available Online:

10February 2020

\section{A B S T R A C T}

A field experiment was conducted at Department of Vegetable Science, College of Horticulture, GKVK Campus, Bengaluru during Rabi Season of 2018-19 to study the effect of fertigation levels on available nutrients status of soil and nutrients uptake by cabbage. The experiment was laid out in RCBD with seven treatments replicated thrice. The treatments included three different dosages of fertilizer (100, 75 and 50\% RDF) and each dose of fertilizers was applied in 12 and 6 equal splits at 5 and 10 days intervals, respectively and they were compared with soil application of 100\% RDF (150: 100: 125 $\mathrm{kg} \mathrm{NPK} \mathrm{ha-1}$ ). The phosphorus was applied as basal dose through soil application while nitrogen and potassium were applied through fertigation. The results revealed that application of $100 \%$ RDF in 12 equal splits at 5 days interval showed significantly lower $\mathrm{pH}$ of 5.84 and higher soluble salt content of soil $\left(0.57 \mathrm{dS} \mathrm{m}^{-1}\right)$. The soil application of $100 \%$ RDF recorded significantly maximum available nitrogen $\left(340.93 \mathrm{~kg} \mathrm{ha}^{-1}\right)$ and phosphorus $\left(47.93 \mathrm{~kg} \mathrm{ha}^{-1}\right.$ ) content of soil while significantly maximum available potassium content $\left(146.50 \mathrm{~kg} \mathrm{ha}^{-1}\right)$ of soil was recorded with application of $100 \% \mathrm{RDF}$ through drip in 6 equal splits at 10 days interval. The significantly maximum total uptake of NPK $\left(159.85,62.35\right.$ and $117.35 \mathrm{~kg} \mathrm{ha}^{-1}$ respectively) by cabbage was recorded with application of $100 \%$ RDF in 12 equal splits at 5 days interval using water soluble fertilizers through drip.

\section{Introduction}

Cabbage (Brassica oleracea L.var. capitata) belongs to the family crucifereae is one of the important vegetables among the cole crops and grown in almost all parts of the world. It is the most popular vegetable around the world with respect to area, production and availability almost round the year. It occupies prime place among cole crops due to its delicious taste, flavour and nutritive value. It is used as salad, boiled vegetable and dehydrated vegetable as well as in cooked curries and pickles.

Fertigation is reported to enhance the fertilizer use efficiency owing to the frequent application of fertilizers directly into crop root zone and hence, reduction in fertilizer rates is possible without compromising the 
yield of vegetables. A significant goal in soil fertility research is to develop practices by which crop nutrient requirements are satisfied through maximum uptake of nutrients from minimum quantity of applied fertilizers. Studies have indicated that conventional methods of fertilizer application need to be modified in order to take full advantage of the drip system of irrigation.

Cabbage responds well to fertigation in terms of yield, nutrient use efficiency and water productivity (Shinde et al., 2006). Vegetables are perhaps the most intensively irrigated crops all over the world and more so is cabbage. Despite the widespread use of high frequency irrigation system and fertigation elsewhere in India, not much information is available on different aspects of fertigation on closely grown crops like cabbage.

Therefore, there is a need to study the vital aspect of fertigation involving the dosage of fertilizers, frequency of fertigation, methods of fertilizer application and soil available nutrient status and nutrient uptake. Keeping these points in view, the present study was undertaken to study the "Effect of fertigation levels on available nutrients status of soil and nutrients uptake by cabbage.

\section{Materials and Methods}

A field experiment was conducted at Department of Vegetable Science, College of Horticulture, GKVK Campus, Bengaluru, during Rabi season of 2018-2019, to study the effect of fertigation levels on available nutrients status of soil and nutrients uptake by cabbage. An initial composite soil sample was collected from the experimental site from 0 $22.5 \mathrm{~cm}$ before imposing the treatments. At the end of the experiment, treatment wise soil samples were collected from the same depth in undisturbed experimental site. The soil samples were dried under shade, powdered with wooden mallet, passed through $2 \mathrm{~mm}$ sieve and stored in clean polythene bags for analysis. The soil of experimental site was near neutral in reaction $(\mathrm{pH} 6.50)$, low in soluble salts content $\left(0.36 \mathrm{dS} \mathrm{m} \mathrm{m}^{-1}\right)$ and medium in available nitrogen $\left(300.60 \mathrm{~kg} \mathrm{ha}^{-}\right.$ $\left.{ }^{1}\right)$, phosphorus (40.10 $\left.\mathrm{kg} \mathrm{ha}^{-1}\right)$ and potassium (146.49 $\left.\mathrm{kg} \mathrm{ha}^{-1}\right)$ content.

The experiment was laid in Randomized Complete Block Design (RCBD) with seven treatments replicated thrice. The treatments included the three different doses of fertigation (100, 75 and 50\% RDF) and each dose of fertilizers was applied in 12 and 6 equal splits at 5 and 10 days intervals, respectively and compared with soil application of 100\% RDF (150:100:125 kg NPK ha ${ }^{-1}$ ). The irrespective treatments, phosphorus were applied as basal dose through soil application whereas nitrogen and potassium were applied through fertigation.

The soil samples were analysed for their chemical composition like $\mathrm{pH}, \mathrm{EC}$ and available nitrogen, phosphorous and potassium content as per the standard procedure outlined below. The $\mathrm{pH}$ of soil water suspension $(1: 2.5)$ was determined by using a bench top professional $\mathrm{pH}$ meter (Model BP3001) having combined electrodes as described by Jackson (1973). The electrical conductivity of clear soil-water extract was determined in the 1:2.5 soil-water suspension using conductivity meter (Model BC3020) and results were expressed in $\mathrm{dS} \mathrm{m} \mathrm{m}^{-1}$ as outlined by Jackson (1973).

Available nitrogen content of soil was estimated by following alkaline potassium permanganate method as described by Subbaiah and Asija (1956). The available phosphorus content of soil was extracted with Brays extractant-I and the amount of phosphorus in the extract was estimated at $660 \mathrm{~nm}$ wavelength using spectrophotometer 
as outlined by Jackson (1973). Available potassium content of soil was determined by extracting with neutral normal ammonium acetate at 1:5 soil to extractant ratio and potassium content in the soil extract was measured using flame photometer (Jackson, 1973). The whole plant samples were collected at the final harvest and were dried under shade and then in hot air oven at $75^{\circ} \mathrm{C}$ till constant weight was obtained and then powdered with micro willey mill. One gram of powered sample was pre-digested with 5 $\mathrm{mL}$ of concentrated nitric acid and was kept overnight. It was digested on a hot plate with diacid mixture $\left(\mathrm{HNO}_{3}: \mathrm{HClO}_{4}\right.$ in $10: 4$ ratio) until either gelatinous white residue or colourless liquid was formed.

It was cooled and made to a known volume with distilled water. This extract was used for analysis of total phosphorus and total potassium content of plant sample (Piper, 1966). For the determination of total nitrogen content of plant sample, $0.5 \mathrm{~g}$ of powdered plant sample was digested with concentrated sulphuric acid in presence of digestion mixture $\left(\mathrm{K}_{2} \mathrm{SO}_{4}: \mathrm{CuSO}_{4}: \mathrm{Se}\right.$ in $100: 20: 1$ ratio) by boiling till a bluish-green residue was formed. The nitrogen in the digested sample was estimated by Kjeldahls distillation method as per the procedure described by Piper (1966). The amount of total nitrogen uptake by the crop was calculated using the following formula.

$\%$ Total N content of plant x Plant dry matter yield $\left(\mathrm{kg} \mathrm{ha}^{-1}\right)$ Nitrogen uptake $\left(\mathrm{kg} \mathrm{ha}^{-1}\right)=$

The phosphorous content of the diacid digested plant sample was determined by Vanadomolybdate yellow colour method (Piper, 1966) by measuring the absorbance of the aliquot of digested sample using spectrophotometer at $430 \mathrm{~nm}$. The amount of total phosphorous uptake by the crop was calculated using the following formula.

Phosphorous uptake $\left(\mathrm{kg} \mathrm{ha}^{-1}\right)$
$\%$ Total P content of plant x Plant dry matter yield $\left(\mathrm{kg} \mathrm{ha}^{-1}\right)$
The potassium content of the diacid digested sample was determined by flame photometric method as described by Piper (1966). The amount of total potassium uptake by the crop was calculated by following formula.

Potassium uptake $\left(\mathrm{kg} \mathrm{ha}^{-1}\right)$

$\%$ Total $\mathrm{K}$ content of plant $\mathrm{x}$ Plant dry matter yield $\left(\mathrm{kg} \mathrm{ha}^{-1}\right)$

100

\section{Results and Discussion}

A cursory glance of results revealed that the soils supplied with $100 \%$ RDF in 12 equal splits at 5 days interval showed significantly lower $\mathrm{pH}$ value (5.84) over all other treatments tried (6.11 to 6.49). However, the $\mathrm{pH}$ of all soils were slightly to moderately acidic in reaction and it was decreased over the initial soil $\mathrm{pH}$ of 6.50 . The soil showed decreasing $\mathrm{pH}$ values with increasing fertilizers doses (Table 1). This might be attributed to accumulation of acids in the upper soil layer, due to acidic nitrogenous fertilizer application.

The total soluble salts content of soils was significantly higher in soils supplied with $100 \%$ RDF in 12 equal splits at 5 days interval $\left(0.57 \mathrm{dS} \mathrm{m}^{-1}\right)$ over all other treatments tried $\left(0.28\right.$ to $\left.0.42 \mathrm{dS} \mathrm{m}^{-1}\right)$. On the other hand, total soluble salts content of soils was significantly lower in soils supplied with $50 \%$ RDF in 6 equal splits at 10 days interval $\left(0.28 \mathrm{dS} \mathrm{m}^{-1}\right)$ followed by application of $50 \%$ RDF in 12 equal splits at 6 days interval (0.29 $\left.\mathrm{dS} \mathrm{m}^{-1}\right)$. But in all treatments, it was within the limits for optimum plant growth. The perusal of the EC values under different treatments indicated higher EC values at the higher fertilizer level, which might have resulted due to higher residual salts in the soil (Table 1). These results are in close conformity with the finding of Tambe et al., (2015).

The available primary nutrient status of soil 
after harvest of crop differed significantly due to different fertigation levels (Table 1). The soil application of $100 \%$ RDF recorded maximum available nitrogen $\left(340.93 \mathrm{~kg} \mathrm{ha}^{-1}\right)$ and phosphorus $\quad(47.93 \quad \mathrm{~kg}$ $\mathrm{ha}^{-1}$ ) content of soil while significantly maximum available potassium content (146.50 $\mathrm{kg} \mathrm{ha}^{-1}$ ) of soil was recorded with fertigation of $100 \%$ RDF (150:100:125 kg NPK $\mathrm{ha}^{-1}$ ) in 6 equal splits at 10 days intervals than rest of the treatments tried.

Whereas, the minimum values of soil available nitrogen (258.27 $\left.\mathrm{kg} \mathrm{ha}{ }^{-1}\right)$ and potassium $\left(121.67 \mathrm{~kg} \mathrm{ha}^{-1}\right)$ were noticed in $\mathrm{T}_{3}$ (treatment application of 50\% RDF in 6 equal splits at 10 days intervals) but minimum available phosphorus (22.75 $\mathrm{kg} \mathrm{ha}^{-1}$ ) was noticed in $\mathrm{T}_{4}$ (treatment application $100 \%$ RDF in 12 equal splits at 5 days intervals).

A cursory glance of results revealed that available nitrogen content of soil increased with increasing fertilizer levels and also varied with method of application. The higher available nitrogen content of soil was found in case of soil application whereas lower in case of fertigation. This might be due to higher uptake of nitrogen by crop if applied thorough fertigation.

The available nitrogen, phosphorus and potassium content of soil generally showed increasing trend with increasing fertilizer doses. The increased available nitrogen and potassium in soil with higher level of fertilizer application might be due to direct contribution towards the available nitrogen and potassium pools in the soil. These results are in agreement with those reported by Shinde et al., (2006), Tanpure et al., (2007) and Tambe et al., (2015).

The nutrient uptake was significantly influenced due to different fertigation levels (Table 2). Fertigation with $100 \%$ RDF
(150:100:125 kg NPK ha $\left.{ }^{-1}\right)$ in 12 equal splits at 5 days interval registered higher total nutrient uptake of $\mathrm{N}, \mathrm{P}$ and $\mathrm{K}(159.85,62.35$ and $117.35 \mathrm{NPK} \mathrm{kg} \mathrm{ha}{ }^{-1}$, respectively) by the cabbage. While, the lowest total nutrient uptake was observed due to soil application of $100 \%$ RDF (109.67, 12.17 and $67.17 \mathrm{~kg} \mathrm{NPK}$ $\mathrm{ha}^{-1}$, respectively).

The total uptake of $\mathrm{N}, \mathrm{P}$ and $\mathrm{K}$ by cabbage increased with increasing fertilizer doses. The significant increase in $\mathrm{N}, \mathrm{P}$ and $\mathrm{K}$ uptake by cabbage with the increasing levels of fertigation was due to the effect of higher yield along with higher $\mathrm{N}, \mathrm{P}$ and $\mathrm{K}$ content in head. The content and uptake of any nutrient in the plant is directly related to the availability in the feeding zone and growth of plant. Thus, increasing in the dose of N, P and $\mathrm{K}$ might have resulted in higher content and uptake of these nutrients in cabbage. These results were in close agreement with the findings of Yang and Guan (1995). The probable explanation of this result is better utilization of $\mathrm{N}, \mathrm{P}$ and $\mathrm{K}$ with increased rate of fertigation levels and frequency of application.

The higher availability of nutrients boosted the vegetative growth, increased photosynthesis and longer roots to absorb nutrients efficiently resulted in higher nutrient uptake. These results are in agreement with those reported by Salo et al., (2002) and Ekad (2003).

The data obtained revealed that the uptake of $\mathrm{N}, \mathrm{P}$ and $\mathrm{K}$ was higher with split application of fertilizer at 6 and 12 days intervals as compared to soil application within the same fertilizer levels which may be explained in the light of continuous availability of nutrient at different stages of plant growth through splits doses which resulted in better accumulation of these nutrients in the plant parts. 
Table.1 Effect of fertigation levels on soil reaction, total soluble salts content and available primary nutrients status of soil after harvest of cabbage

\begin{tabular}{|c|c|c|c|c|c|c|}
\hline & Treatments & $\mathbf{p H}$ & EC & Avail. $\mathbf{N}$ & Avail. $\mathbf{P}_{2} \mathbf{O}_{5}$ & Avail. $\mathrm{K}_{2} \mathrm{O}$ \\
\hline $\mathbf{T}_{1}$ & $100 \%$ RDF (150:100:125 $\left.\mathrm{kg} \mathrm{NPK} \mathrm{ha}^{-1}\right)$ in 6 equal splits at 10 days intervals & 6.11 & 0.42 & 308.10 & 40.10 & 146.50 \\
\hline $\mathbf{T}_{\mathbf{2}}$ & $75 \%$ RDF (112.5:75:93.75 $\left.\mathrm{kg} \mathrm{NPK} \mathrm{ha}^{-1}\right)$ in 6 equal splits at 10 days intervals & 6.27 & 0.31 & 280.97 & 39.22 & 131.87 \\
\hline $\mathbf{T}_{3}$ & $50 \%$ RDF (75:50:62.5 kg NPK ha $\left.{ }^{-1}\right)$ in 6 equal splits at 10 days intervals & 6.42 & 0.28 & 258.27 & 42.77 & 121.67 \\
\hline $\mathbf{T}_{\mathbf{4}}$ & $100 \%$ RDF (150:100:125 $\left.\mathrm{kg} \mathrm{NPK} \mathrm{ha}^{-1}\right)$ in 12 equal splits at 5 days intervals & 5.84 & 0.57 & 290.78 & 22.75 & 129.15 \\
\hline $\mathbf{T}_{\mathbf{5}}$ & $75 \%$ RDF (112.5:75:93.75 $\left.\mathrm{kg} \mathrm{NPK} \mathrm{ha}^{-1}\right)$ in 12 equal splits at 5 days intervals & 6.24 & 0.36 & 278.07 & 36.32 & 128.97 \\
\hline $\mathbf{T}_{6}$ & $50 \%$ RDF (75:50:62.5 kg NPK ha ${ }^{-1}$ ) in 12 equal splits at 5 days intervals & 6.39 & 0.29 & 261.34 & 45.84 & 124.74 \\
\hline $\mathbf{T}_{7}$ & Control (Soil application of 100\% RDF 150:100:125 kg NPK ha ${ }^{-1}$ ) & 6.49 & 0.28 & 340.93 & 47.93 & 141.83 \\
\hline & S.Em \pm & 0.06 & 0.01 & 4.82 & 0.67 & 1.44 \\
\hline & CD@ $@ 5 \%$ & 0.19 & 0.02 & 15.03 & 2.09 & 4.51 \\
\hline
\end{tabular}


Table.2 Nitrogen, phosphorus and potassium uptake $\left(\mathrm{kg} \mathrm{ha}^{-1}\right)$ by head and stalk of cabbage as influenced by fertigation levels

\begin{tabular}{|c|c|c|c|c|c|c|c|c|c|c|}
\hline \multicolumn{2}{|r|}{ Treatments } & \multicolumn{3}{|c|}{ N uptake (kg ha $\left.{ }^{-1}\right)$} & \multicolumn{3}{|c|}{ P uptake ( $\left.\mathrm{kg} \mathrm{ha}^{-1}\right)$} & \multicolumn{3}{|c|}{ K uptake (kg ha $\left.{ }^{-1}\right)$} \\
\hline & & Head & Stalk & Total & Head & Stalk & Total & Head & Stalk & Total \\
\hline $\mathbf{T}_{1}$ & $\begin{array}{l}\left.\text { 100\% RDF (150:100:125 } \mathrm{kg} \mathrm{NPK} \mathrm{ha}^{-1}\right) \text { in } 6 \text { equal splits at } 10 \\
\text { days intervals }\end{array}$ & 121.60 & 20.90 & 142.50 & 37.11 & 7.89 & 45.00 & 85.37 & 14.63 & 100.00 \\
\hline $\mathbf{T}_{2}$ & $\begin{array}{l}\left.75 \% \text { RDF (112.5:75:93.75 } \mathrm{kg} \mathrm{NPK} \mathrm{ha}^{-1}\right) \text { in } 6 \text { equal splits at } \\
10 \text { days intervals }\end{array}$ & 115.02 & 17.11 & 132.13 & 28.71 & 5.92 & 34.63 & 76.55 & 13.08 & 89.63 \\
\hline $\mathbf{T}_{\mathbf{3}}$ & $\begin{array}{l}\left.50 \% \text { RDF (75:50:62.5 } \mathrm{kg} \mathrm{NPK} \mathrm{ha}^{-1}\right) \text { in } 6 \text { equal splits at } 10 \\
\text { days intervals }\end{array}$ & 90.30 & 27.03 & 117.33 & 16.71 & 3.12 & 19.83 & 63.99 & 10.84 & 74.83 \\
\hline $\mathbf{T}_{4}$ & $\begin{array}{l}\left.\text { 100\% RDF (150:100:125 } \mathrm{kg} \mathrm{NPK} \mathrm{ha}^{-1}\right) \text { in } 12 \text { equal splits at } 5 \\
\text { days intervals }\end{array}$ & 135.60 & 24.25 & 159.85 & 51.46 & 10.89 & 62.35 & 100.24 & 17.11 & 117.35 \\
\hline $\mathbf{T}_{5}$ & $\begin{array}{l}\left.75 \% \text { RDF (112.5:75:93.75 } \mathrm{kg} \mathrm{NPK} \mathrm{ha}^{-1}\right) \text { in } 12 \text { equal splits at } \\
5 \text { days intervals }\end{array}$ & 116.30 & 18.73 & 135.03 & 30.80 & 6.73 & 37.53 & 78.92 & 13.61 & 92.53 \\
\hline $\mathbf{T}_{6}$ & $\begin{array}{l}\left.50 \% \text { RDF (75:50:62.5 } \mathrm{kg} \mathrm{NPK} \mathrm{ha}^{-1}\right) \text { in } 12 \text { equal splits at } 5 \\
\text { days intervals }\end{array}$ & 99.58 & 14.68 & 114.26 & 14.15 & 2.61 & 16.76 & 61.26 & 10.50 & 71.76 \\
\hline $\mathbf{T}_{7}$ & $\begin{array}{l}\text { Control (Soil application of 100\% RDF 150:100:125 kg NPK } \\
\mathrm{ha}^{-1} \text { ) }\end{array}$ & 97.14 & 12.53 & 109.67 & 10.33 & 1.84 & 12.17 & 57.26 & 9.91 & 67.17 \\
\hline & S.Em \pm & 0.84 & 0.27 & 2.11 & 0.48 & 0.11 & 0.46 & 1.12 & 0.24 & 0.96 \\
\hline & CD@ 5\% & 2.63 & 0.85 & 6.58 & 1.52 & 0.35 & 1.45 & 3.51 & 0.75 & 3.01 \\
\hline
\end{tabular}


The increased uptake of nitrogen with increasing fertigation levels was due to supply of added nutrients on account of proliferous root system developed under balanced nutrient application which resulted in better absorption of water and nutrients. Yang and Guan (1995) also reported significant improvement in the uptake of nitrogen in cabbage.

From the present investigation, it can be concluded that application of $100 \% \mathrm{RDF}$ (150:100:125 kg NPK ha ${ }^{-1}$ ) in 12 and 6 equal splits at 5 and 10 days intervals, respectively through drip irrigation with water soluble fertilizes (WSF) is ideal to enhance maximum available nutrients status of soil and total nutrients uptake by cabbage.

\section{References}

Ekad, S. K., 2003, Studies on fertigation for cabbage (Brassica oleraceae var. Capitata L.). M.Tech. (Agril. Engg.) Thesis submitted to Mahatma Phule Krishi Vidyapeeth, Rahuri, Maharashtra.

Jackson, M. L., 1973, Soil Chemical Analysis. Prantice Hall of India Pvt. Ltd., New Delhi, pp. 370-389.

Piper, C. S., 1966, Soil and Plant Analysis.
Hans Publishers, Mumbai. pp. 19-136.

Salo, T., Suojala, T. and Kallela, M., 2002, The effect of fertigation on yield and nutrient uptake of cabbage, carrot and onion. Acta-Hort., 571: 235-241.

Shinde, P. P., Chavan, M. G. and Newase, V. B., 2006, Studies on fertigation in cabbage. J. Maharashtra Agric. Univ., Pune (India). 31(3): 255-257.

Subbaiah, B. V. and Asija, G. L., 1956, A rapid procedure for estimation of available nitrogen in soils. Curr. Sci., 25: 259-260.

Tanpure, S. N., Patil, P. V., Pingale, L.V., Gutal, G. B. and Bote, N. L., 2007, Effect of different levels of fertilizer application on yield of cabbage. $J$. Maharashtra Agric. Univ., 32(1): 151152.

Tambe, A. J., Dhawan, A. S. and Gourkhede, P. H., 2015, Effect of Integrated Nutrient Management on Yield, Quality Improvement and Nutrient Uptake of Chilli. Int. J. Trop. Agri., 33(4): 37773781.

Yang, X. and Guan, P. C., 1995, Influence of NPK nutrients on texture, quality and nutrient accumulation in heads of green flowered broccoli. Guangdong. Agri. Sci., 6: 21-23.

\section{How to cite this article:}

Mohammadullah Nikzad, J. S. Aravinda Kumar, B.N. Dhananjaya, M. Anjanappa, and Amarananjundeswara. H. 2020. Int.J.Curr.Microbiol.App.Sci. 9(02): 1856-1862.

doi: https://doi.org/10.20546/ijcmas.2020.902.212 